\title{
Bushmeat and the North-East Way: A Conflict between Wildlife and Humans
}

Konsam Jenny is working as a Guest Faculty at the Department of Political Science, Manipur University. She has worked as Assistant Professor at Don Bosco College, Golaghat, Assam and was a Lecturer at St. Joseph College, Ukhrul, Manipur.

\begin{abstract}
Bushmeat, which has become the rich man's delicacy, was once the food of the poor. The increase in the demand for bushmeat has hampered the population of wildlife to a great extent. Wildlife is exploited not only for food but also for other reasons such as fun, as an expression of valour, as a cultural practice, for preparation of traditional medicines, for protection against these animals, for trade, and others. Consumption of bushmeat, deforestation, climate change, etc., have led to an increase in human conflicts with wildlife which in turn has caused a number of Emerging Infectious Diseases (EIDs) like AIDS, HIV, Ebola, Swine Flu, Black Death, Polio, Dengue Hemorrhagic Fever etc. Although, hunting is banned in India since 1972 under Wildlife Protection Act, it is still continuing as there is a huge international market for wildlife products. Moreover, when it comes to North-East, the issue becomes ever more complex as it is closely connected to its culture and traditions. This paper will provide a general study of bushmeat in North-East India and the depleting number of wildlife species which will later create an inevitable conflict between the human race and wildlife.
\end{abstract}

Key Words: Bushmeat, North-East, Wildlife, Diseases, Culture and Tradition

Bushmeat, which was once consumed only by the poor, and in remote areas especially in Africa, as a primary source of animal protein in the diet, is no longer the food of the poor. Today, it has become a delicacy enjoyed only by the rich. The Resolution 2.64 of 
Salesian Journal of Humanities and Social Sciences, Vol. X, No. 1. (May 2019)

ISSN: 0976-1861 | DOI: 10.51818/SJHSS.10.2019.16-23 | Page: 16-23,

Section: Article

the General Assembly of the International Union for Conservation of Nature (IUCN) in Amman in October 2000 referred to 'wild meat' rather than 'bushmeat'. Before going any further, it is important to understand what bushmeat means. Bushmeat, also known as wild meat or game meat, is meat from non-domesticated mammals, reptiles, amphibians and birds hunted for food in tropical forests. ${ }^{1}$ Today, the term bushmeat is commonly used for meat of terrestrial wild or feral mammals, killed for sustenance or commercial purposes throughout the humid tropics of the Americas, Asia, and Africa. ${ }^{2}$

\section{Bushmeat and its Varieties}

According to a Report by some Conservationists: monkeys, pythons, Chinese pangolins, great barbets, civets, leopard cats, Asian forest tortoises and many other species of wildlife are on sale in the markets of Tamenglong in Manipur. Many of these species are on the endangered list ${ }^{3}$ especially the Chinese Pangolins. ${ }^{4}$ In Arunachal Pradesh, according to one article, a total of 33 mammalian species are reportedly hunted of which 20 are endangered, vulnerable or near threatened on the IUCN Red List. ${ }^{5}$ In Nagaland, according to one article, apart from mollusks and amphibians, 1870 birds of 35

1 Nasi, R., Brown, D., Wilkie, D., Bennett, E., Tutin, C., van Tol, G., and Christophersen, T. Conservation and use of wildlife-based resources: the bushmeat crisis, (Secretariat of the Convention on Biological Diversity, Montreal, and Center for International Forestry Research: 2008), Bogor Technical Series no. 33, 50.

2 "Bushmeat", wikipedia, accessed February 04, 2018, https://en.wikipedia.org/ wiki/Bushmeat.

${ }^{3}$ Daniel Manipurby and Galina Macwan "Chinese Pangolin, Tamenglong Market", http:/ / www.conservationindia.org/gallery/chinese-pangolin-tamenglongmarket-manipur.

${ }^{4}$ The Chinese Pangolin is listed as Critically Endangered as per the IUCN Red List due to high levels of poaching for meat and scales across its range. In India, this species is legally protected, being listed in Schedule I of the Wildlife Protection Act 1972 (amended 2003, 2006), but the story on the ground is entirely different in Daniel and Galina Macwan "Chinese Pangolin, Tamenglong Market, Manipur" accessed March 04, 2018, http://www.conservationindia.org/gallery/chinesepangolin-tamenglong-market-manipur.

${ }^{5}$ Ambika Aiyadurai et al., "Wildlife hunting by indigenous tribes: a case study from Arunachal Pradesh, North-East India", The International Journal of Conservation, (2010), 1-9 


\section{8 / Konsam Jenny}

Salesian Journal of Humanities and Social Sciences, Vol. X, No. 1. (May 2019) ISSN: 0976-1861 | DOI: 10.51818/SJHSS.10.2019.16-23 | Page: 16-23,

Section: Article

different species, 512 mammals of 8 different species were hunted and eaten. ${ }^{6}$ Not only in North-East but also in other parts of India wild animals are hunted and eaten. According to Samir Sinha, Head of Traffic-India,

Anything and everything you can think of is eaten, the most commonly consumed ones are pheasants, partridges, spotted and barking deer, and wild boar, but there's a demand for many other wild species. ${ }^{7}$

Kartick Satyanarayanan of Wildlife SOS, said,"Bisons are eaten in Bandipur, bear-paw soup in Orissa, monitor lizards and porcupines are eaten everywhere they are found, and civet cats, jackals, hedgehogs, pangolins are eaten in the South.... The list is endless." ${ }^{8}$

Ambika Appadurai (a wildlife researcher) is of the opinion that, "The majority of the villagers prefer wild meat because it's considered delicious and also believed to be non-contaminated like the meat of domestic animals that eat refuse found around the villages." ${ }^{\prime \prime}$

\section{Bushmeat and Diseases}

Lately, the world is witnessing an increase in the number of Emerging Infectious Diseases (EID).$^{10}$ According to one article by Jeanna Bryner, about 60 per cent of all human diseases and 75 per cent of all emerging infectious diseases are zoonotic which comes from livestock, including pigs, chickens, cattle, goats, sheep and camels. ${ }^{11}$ Diseases, such as Ebola (in 2014), Swine Flu (in 2009 and

${ }^{6}$ Wildlife exploitation: a market survey in Nagaland, north-eastern India by Subramanian Bhupathy et al (2013)

7 "Love for bushmeat: India's rare species at risk", accessed February 20, 2018, http:/ / southasia.oneworld.net/archive/Article/love-for-bushmeat-indias-rarespecies-at-risk\#.WovVC1RubDc.

8 "Love for bushmeat"

${ }^{9}$ Ibid.

${ }^{10}$ Jones et al., "Global trends in emerging infectious diseases," Nature, no. 451 (2008): 990-993.

${ }^{11}$ Jeanna Bryner, "Animal-to-Human Diseases Kill 2.2 Million People Each Year", accessed June 6, 2018, https://www.livescience.com/21426-global-zoonoses- 
Salesian Journal of Humanities and Social Sciences, Vol. X, No. 1. (May 2019) ISSN: 0976-1861 | DOI: 10.51818/SJHSS.10.2019.16-23 | Page: 16-23,

Section: Article

2015) ${ }^{12}$, Spanish Flu (in 1918), influenza, Polio, HIV, Marburg, Lassa, Nipah, Rift Valley Fever, AIDS $^{13}$ etc., are just few examples of EID. In addition, diseases such as Leptospirosis is spread from rodents and cattle; Brucellosis from cattle, sheep and goat; Bovine Tuberculosis spreads from cattle; Anthrax from dead animals, usually cattle; Avian Flu spreads from poultry to humans; Rabies from dogs; Severe Acute Respiratory Syndrome (SARS), which was initially a zoonotic disease, ${ }^{14}$ is now spread from human to human, etc. It is almost 100 per cent fatal but is also 100 per cent preventable. A research team, headed by Nathan Wolfe at Global Viral Forecasting Initiative, which worked on zoonotic diseases, draws the conclusion that evolution of EID can be traced to animals of different species and the interaction between wild animals and humans, which provide new travel destinations for microbes. ${ }^{15}$

\section{Bushmeat and Trade}

Today, bushmeat is taking a different turn. Not only the meat is consumed but the body parts (almost all) of game are in high demand in the international markets making a multi-million dollar industry. ${ }^{16}$ As for example, most of the pangolin species and its derivatives are destined to Myanmar, China, Nepal, Vietnam and Thailand via through the border state of Manipur, Nagaland, Assam, Mizoram, Meghalaya and Arunachal Pradesh. Moreover,

diseases-hotspots.html.

${ }^{12}$ Dovih, Pilot, "Bat Hunts and Disease Outbreaks: Traditional Bat Hunting in Nagaland", Economic \& political Weekly, no. 50 (2015): 18.

13 "A beast of a problem The illegal trade in wild-animal meat could cause the next global pandemic", accessed January 16, 2018, https:/ / qz.com/795294/will-illegalbushmeat-bring-the-next-global-outbreak/.

${ }^{14}$ Zoonotic disease is a disease that is naturally transmissible from animals to people.

15 Rebecca Kreston, "Beating around the Bush: Bushmeat \& Emerging Diseases", Discover, (blog), March 18, 2011, http://blogs.discovermagazine. com/bodyhorrors/2011/03/18/beating-around-the-bush-bushmeat-emergingdiseases/\#.WpuVvehuZPY.

16 “The Bush Meat Trade: Not Just Africa's Problem”, accessed February 22, 2018, http:/ / www.onegreenplanet.org/animalsandnature/the-bush-meat-trade-notjust-africa-problem/. 


\section{0/ Konsam Jenny}

Salesian Journal of Humanities and Social Sciences, Vol. X, No. 1. (May 2019) ISSN: 0976-1861 | DOI: 10.51818/SJHSS.10.2019.16-23 | Page: 16-23,

Section: Article

bushmeat, which was consumed by the poor and indigenous people in remote areas as a supplement diet, today, has become a luxurious item and the only reason for not eating is that it is too expensive. ${ }^{17}$ Another factor that drives the hunting of wild animals is the use of their body parts in the preparation of traditional medicines. As for example, in Arunachal Pradesh, Bear gall bladder is used in traditional Asian medicine, which is later sold in Assam; fat from the base of the monitor lizard's tail, is melted down and sold in little bottles as an aphrodisiac; gall bladder of sloth bears is used for curing rheumatism; rings fashioned out of the pangolin's scales are sold at village haats as charms to ease haemorrhoids and labour pain; the slow loris, a meek, saucer-eyed arboreal creature, is eaten to bring down raging fevers. ${ }^{18}$

\section{Bushmeat Culture and Tradition: North-East India and its Complexity}

One cannot deny the fact that the customs and traditions are bedrock of a society and govern social, cultural, environmental and economic ties. ${ }^{19}$ In some parts of North-east India, central India, and Andaman and Nicobar islands, under the garb of customs and traditions, wildlife is hunted every year for food, trade, entertainment, traditional medicine etc. In many parts of the country, among many indigenous communities, wildlife and its products form an integral part of livelihood. In many communities hunting is a sign of masculinity. One who does not hunt may be viewed with poor pixels and less zoom through the social lens. ${ }^{20}$

\footnotetext{
17 "'Boom' and gloom: Forest-based wildlife feel brunt of Asia's appetite for meat, medicine", accessed January 16, 2018, https://forestsnews.cifor.org/26999/wildmeat-forests-southeast-asia-bushmeat-traditional-medicine-wildlife?fnl=en.

18 "Love for bushmeat: India's rare species at risk", accessed February 20, 2018, http:/ / southasia.oneworld.net/archive/Article/love-for-bushmeat-indias-rarespecies-at-risk\#.WovVC1RubDc.

${ }^{19}$ Rajesh A M, "Customs, Traditions and the Conundrum of Environment (Wildlife) Conservation in Manipur", accessed February 03, 2018, http://www.ifp.co.in/ page/items/34504/customs-traditions-and-the-conundrum-of-environmentwildlife-conservation-in-manipur/.

${ }^{20}$ Rajesh A M, "Customs, Traditions and the Conundrum of Environment (Wildlife) Conservation in Manipur".
} 
Salesian Journal of Humanities and Social Sciences, Vol. X, No. 1. (May 2019)

ISSN: 0976-1861 | DOI: 10.51818/SJHSS.10.2019.16-23 | Page: 16-23,

Section: Article

Practice and customs linked take a long time to change, often they are resistant and slow ${ }^{21}$ which is very much prevalent in NorthEast India. As for example, giving fresh or dried wild meat is a traditional practice during weddings in Arunachal Pradesh. ${ }^{22}$ Often wild meat is offered as a bride price during weddings and is regarded as a status symbol. Visiting officials are gifted with wildlife products or meat as a symbol of respect and officers are presented with animal skins for decorative purpose. ${ }^{23}$ Sacrificing of wild as well as domestic animals are part of rituals. ${ }^{24}$ Villagers often rely on local priests and healers who recommended the use of domestic meat for curing illnesses ${ }^{25}$ and many more. Looking at the above scenario, it is very difficult, especially in north-east India, to tackle this problem. In addition, the presence of traditional laws, which are implemented by a legally empowered village council, ${ }^{26}$ make the laws of the Government not very effective.

\section{Governmental Laws and Acts for the Protection of Environment}

The Wildlife Protection Act, 1972, enacted for protection of plants and animal species, and Biological Diversity Act, 2002, an Act of the Parliament of India for preservation of biological diversity in India, provide mechanism for equitable sharing of benefits arising

${ }^{21}$ Rohit Naniwadekar, "Wildlife Hunting in the North East is much more complex than the simple act of killing", accessed February 04, 2018, https://scroll.in/ article/822350/wildlife-hunting-in-the-north-east-is-much-more-complex-thanthe-simple-act-of-killing.

${ }^{22}$ Ambika Aiyadurai, Navinder J. S ingh and E. J. Milner-Gulland, “Wildlife hunting by indigenous tribes: a case study from Arunachal Pradesh, north-east India" The International Journal of Conservation, (October 2010): 1-9.

${ }_{23}$ "Wildlife hunting in the North East is much more complex than the simple act of killing", accessed January 04, 2018, https://scroll.in/article/822350/wildlifehunting-in-the-North-East-is-much-more-complex-than-the-simple-act-of-killing.

${ }^{24}$ Ambika Aiyadurai, Navinder J. S ingh and E. J. Milner-Gulland, “Wildlife hunting by indigenous tribes"

${ }^{25}$ Ibid.

${ }^{26}$ Nandini Velho and William F. Laurence, "Hunting practices of an IndoTibetan Buddhist tribe in Arunachal Pradesh, north-east India", https:// www.cambridge.org/core/journals/oryx/article/hunting-practices-ofan-indotibetan-buddhist-tribe-in-arunachal-pradesh-northeast-india/ E3304014F13B5166B936DA60DA9A0E13. 


\section{2 / Konsam Jenny}

Salesian Journal of Humanities and Social Sciences, Vol. X, No. 1. (May 2019) ISSN: 0976-1861 | DOI: 10.51818/SJHSS.10.2019.16-23 | Page: 16-23,

Section: Article

out of the use of traditional biological resources and knowledge. Constitution of India imposes moral responsibility on the state to make necessary legislations to protect environment under Article 48A, which was added to the Directive Principles of State Policy under the Constitution (42nd Amendment) Act. 1976. Article 48A states that the State shall endeavor to protect and improve the environment and to safeguard the forests and wildlife of the country. Article 51A of the Indian Constitution (42nd Amendment) Act, 1976 and Article 51A (g), specifically deals with the fundamental duty of citizens with respect to environment. It provides, "it shall be the duty of every citizen of India to protect and improve the natural environment including forests, lakes, rivers and wild life and to have compassion for living creatures." 27

\section{Conflict between Human and the Environment}

When it comes to environment and wildlife, one cannot neglect the existing conflict between humans and the wild animals. As mentioned above, wild animals have a very complicated relation with socio-economic and culture ${ }^{28}$ with that of north east people of India. No doubt, in certain area environmental good like hunted wildlife satisfies some use, may be in the form of food or unproved medicinal properties, must not be used as a tool to justify hunting. The proper rule must be to sacrifice human needs to protect wildlife or any other environmental good. ${ }^{29}$ Consumption and medicine habits should not be an excuse for hunting of wildlife. ${ }^{30}$ One must not be negligent of the fact that the wildlife, which is an important indicator of environmental health, also provides important ecosystem services. ${ }^{31}$

\footnotetext{
${ }^{27}$ Rajesh A M, “Customs, Traditions and the Conundrum of Environment (Wildlife) Conservation in Manipur".

${ }^{28} \mathrm{Ibid}$

${ }^{29}$ Ibid.

${ }^{30}$ Ibid.

${ }^{31}$ Ibid.
} 


\section{Conclusion}

It is a very sad reality that our food habits, culture and beliefs are contributing to extinction risk of many wild animals. Moreover, with a huge international market for bushmeat it is very difficult to keep in check such risk. These meats are regarded as dainties to many especially in urban areas. Coming to North-East India, the situation becomes complex as the consumption of bushmeat is part and parcel of its culture. Moreover, they have their own laws regarding the same which makes the issue of wild meat highly complex. If the intake of bushmeat goes unchecked, it could lead to local extinction of some species, especially in remote regions where law enforcement is weak and long-term hunting has already reduced wildlife populations. 